\title{
Reflection on the Position of English in the Education and Life of the Chinese Today
}

\author{
XIE Bang-xiu \\ Harbin Normal University, Harbin; Hubei University of Police, Wuhan, China
}

\begin{abstract}
Nowadays, English is in a contrasting position in China: It seems to be everywhere throughout a person's life and career; meanwhile, it tends to find no place in people’s real life. As a result, people bear different attitudes toward English. This touches the author so sharply that she feels obliged to write something on it so that more people may notice it, care about it, and do something creative to channel it into a more sustainable and healthy track. So, in this paper, the author describes the conflicting status of English in China, analyzes people's attitudes toward and struggle in coping with English, and criticizes the lack of freedom for people to choose whether or not they want English in their learning or career, the impossibility of people to say "no" to English, and the waste of money, energy, time, and even life itself of people when they are forced to struggle with English. Based on all this, the author tries to offer proposals to harmonize English with people's life. That is, to put English somewhere in people’s learning and career in a more reasonable sense, considering people’s personal interest, emotion, freedom of choice and real need.
\end{abstract}

Keywords: English, education, life, compulsory, freedom

\section{Introduction}

It is not easy to describe the position of English in the life of the present Chinese people. Considering the fact that nearly all the Chinese people, as students of different levels of schools (including primary school, middle school, college, or university), have to take English as a compulsory course at school, and that those who finish with their schooling and want to find a job and those who hope to get promoted in their career have to offer some certificates to prove their English levels, we can safely say that English has influenced, and is influencing, the life of most (if not all) Chinese people. On the other hand, in accordance with the reality that almost all the Chinese people do not have any real need or surroundings to use English in their daily life, it is equally safe for us to say that English stands no where in people's life in China. As a result of such conflicting situation, different people have different attitudes toward the English language in the Chinese context. What is absolutely true is that no one can say "no" to English at school or at work, for no one can afford it due to the compulsory status English is placed in education and in tests for different purposes. Students, parents, teachers, and the whole society tend to lay overstress on it, which put students in even worse situations.

XIE Bang-xiu, professor, School of Education Science, Harbin Normal University; Foreign Language Department, Hubei University of Police. 
This situation touches the author so sharply and deeply that she feels obliged to write something on this topic, so that more people of interest, in China as well as the world through, may notice it, care about it, and might eventually do something creative to change it and channel it into a more sustainable and healthy track.

To know detailed information on this issue, please go on reading.

\section{English Is Everywhere}

In China, the education of foreign languages, mainly of English, have boosted at an unprecedented speed and scale in recent decades. According to a recent survey (ZHANG, 2007, p. 103), at present, for students of different levels (from primary school pupils to doctoral students of universities), the course of a foreign language is compulsory, and English is compulsory for about $90 \%$ of those students. The number of primary and secondary school students who learn English as their compulsory foreign language course has reached a total of over two hundred million. If those who care about their learning, their parents (each two) and their grand parents (each four) are included, then the education of English as a foreign language is affecting the life of nearly one billion Chinese people.

For students who learn English at school in China, most of them do not choose to learn it of their own will, they have to learn it for variously outer reasons, the most unavoidable one of which is that English is a compulsory course for them, like some other courses, such as Chinese, Mathematics, Physics, Chemistry, History, etc.. As a school course, English is becoming more and more important with time going, and is now one of the three most important courses (the so-called three main subjects) in middle school education (the other two being Chinese and Mathematics). Students' performance in learning English and in taking English tests is of vital significance to their total achievements at school, to their opportunities for further learning, and consequently to their future development. In this sense, English means so much to students and their families that no one can escape from it or dare to ignore it.

In fact, English is an influential factor in the whole process of a person's development in learning and in career, and largely affects the quality of their living.

As far as learning is concerned, if a middle school student is successful enough and has managed to pass the College Entrance Examinations and gets the chance to learn further in a college or university, supposing he/she is a non-English major (for the majority of college or university students in China are non-English majors, and the story for English majors is different), he/she has to take a two-year compulsory course of English—College English. In addition to the tests given to them by the college or university at the end of each semester, he/she is supposed to reach a certain level of English and pass a national test for college students-The National College English Test (Band 4 or Band 6) (CET-4 or CET-6) — before graduation, to be issued a CET certificate (or now a report card of CET results) and thus considered qualified as a college graduate. This certificate or report card is of vital importance for him/her to go further in his/her life.

If this student, after his/her undergraduate study, is determined to pursue postgraduate learning, he/she has to take another set of entrance examinations for the opportunity, among which English is to be tested nationally again, of course more demanding than CET-4. If he/she manages to pass all the examinations and becomes a postgraduate student working at the master's degree, he/she has to take a one-year compulsory English course, and is supposed to pass CET- 6 and receive the CET- 6 certificate or report card before graduation. 
Then, if he/she still wants to learn further and to receive a doctor's degree, he/she has to take one more set of entrance examinations for the opportunity, among which English is to be tested again, this time not nationally but given by the university he/she hopes to be enrolled in, even more demanding than any other tests. It actually works as an obstacle blocking many people on their way advancing further in their school learning. If he/she manages to pass all the examinations and becomes a doctoral student, he/she, again, has to take another one-year compulsory English course.

Now let us come to a person's career development. If a person hopes to pursue a career with good pay, stable and respected position, and promising future, he/she has to be a college or university graduate, especially with a CET-4 or CET-6 certificate or report card of the test results, which the employers believe can prove his/her level of English. The CET-4 or CET-6 certificate or report card becomes a necessity for college graduates to find a job.

If this person is outstanding among his/her peers and manages to get a satisfactory position, say, in a hospital, in a research institute, or in a school, he/she is not to bid farewell to English learning, whatever he/she specializes at. If he/she hopes to raise his/her staff rank or has his/her professional title reviewed to reach a higher level, in about every five years at professional work, he/she has to take and pass a set of examinations, in which English is compulsorily included, be he/she a Chinese teacher, a dentist, or a civil engineer.

Thus, as a compulsory course of schools at different levels in China, and as a compulsory item to be tested at different stages of a person's learning and working life, English accompanies a person on the whole way of his/her school learning and career development. Any time when a person hopes to advance, to pursue further learning, and to be promoted in the working place, English is there with him/her, welcomed by the person in question or not. From these we can tell, what great influence English has exercised on the life of the Chinese people, be they students, parents of students, or working people! The time, energy, effort, and money a person poses on his/her English learning far surpass those he/she puts into the learning of Chinese as a school course.

\section{English Is Nowhere}

But when it comes to daily life of ordinary Chinese people, English is nearly nowhere. The Chinese, young and old, male and female, literate and illiterate, are used to thinking, obtaining information, communicating with others, expressing ideas, feelings and emotions, playing games... in a word, doing everything in their life, in Chinese. English has no place in people's real life: It is by no means a necessity to them, and they have no opportunities or settings to use it at all in their daily life. Even those professionals of English-English majors at college or university, teachers of English of schools, colleges or universities, and interpreters or translators, etc., unless necessarily when conducting professional activities (in English), mostly choose to use Chinese instead of English in everyday living.

The author's own story is a good case in point: As a teacher of English in a university in China, the author uses English only on the occasions of preparing for or giving lessons to students in class. And her practice of using English in teaching is among the best approaches of conducting the instruction of English to college students, for some teachers never bother to speak any English even when teaching in class. Out of the working situations, the author never has any chance or environment to use any English, even with her colleagues_other English teachers. They feel strange, awkward, and unnatural if they actually use English to communicate with each other in the whole Chinese surroundings. 
For people of other specialties (than English), although they have taken great pains to have obtained the needed English certificates that are believed to prove their English levels, and managed to get the work they long for, they seldom or never really need to use any English in their actual work, except when preparing for one more test of English to get promoted in their professional career. In fact, most of the working positions do not need any English background, and people can perform fairly well without knowing a word of English. But to get employed in such positions, people must offer certificates that can prove their English levels. How ridiculous it is! What a waste of people’s time, energy, and money!

\section{People's Attitudes Toward English}

Based on the influence that English exerts upon people's life, different people in China bear different attitudes toward English, English education, and English tests and examinations.

It is true that a considerable number of people in China do love English (like the author) or do want or need to learn English well, and they may think that it is okay or right for the government to lay enough emphasis upon English in education. As a matter of fact, whether it is compulsory or not, they choose to learn English of their own will. These people may belong to the lucky and happy group with the compulsory status of English.

However, the majority of the Chinese students, who do not feel any inner call for learning English, who do not have any interest in it, who do not find any necessity to know it or to use it in real life, or who do not like it or even hate it for various reasons, are forced to learn it just because it is a compulsory school course. They are deprived of the freedom to decide whether to learn it or not. Some of them are okay with the situation, which is a reasonable attitude as far as the unchangeable reality (at least to single individuals) is concerned. But some are strongly against being forced to learn it so that they never take any initiative to learn it, they refuse to follow the teachers' instructions, they avoid practicing it in and out of class, they perform poor at tests, and so they hate English and even the English teachers.

In addition, because of the compulsory status English is placed in education and in tests for different purposes, parents, teachers, and the whole society tend to lay overstress on it, which put students in even worse situations.

On the parents part, to make their children (especially primary and middle school children) keep up with or go in advance of their peers in learning, they urge their children to learn more for longer time after school, by forcing them to do more English homework than assigned, sending or accompanying them to have remedial English classes, or inviting tutors to help them learn English at home. Some of the parents, who are very good at English and benefiting much from it themselves, do so because they cannot bear to see their children fall behind others, and hope their children can do as well as or better than themselves; some other parents do so because they feel they themselves were left behind when they were young, and they hope their children can make up for them and realize their dreams; still other parents do so just because others are doing so and they and their children can not afford to fall behind, which may result in their children losing at the starting line compared with other children. Most of the parents make decisions for their children without asking or listening to their children's ideas or feelings. They take it for granted that their children can understand them and agree with them, for what they are doing is for the children's good.

On the teachers' part, their main concern is to make their students perform well in various English tests or examinations, for students' performance, in terms of exam results, in tests of the English course is an important 
criterion to judge and evaluate their levels of teaching and their achievements at work. Their income, promotion, and personal development are largely dependent on such judgment and evaluation. To meet such needs, they care more about whether the students are skillful at answering testing questions than about their real competence of the English language. And with passing some fatal examinations as the final target (as in the case of the middle schools), the main activities of teaching are talking about things connected with the examination, such as grammar rules, skills of answering testing questions, etc., and the main task of learning is to keep in mind the rules and skills, and to practice doing exercises and answering questions on numerous papers. With too many students in one class (usually over 60 students per class in primary and middle schools), it is nearly impossible for teachers to care about students' individual ideas, feelings, or needs on English or on their learning of English in class.

When it comes to the society, on the one hand, because of the compulsory status of English in school education and in different levels of tests, many people need extra help to pass relevant tests and examinations. In response to such needs of the people, there forms an economic chain of remedial English education in the society, including classes or schools of different scales, teachers or trainers offering such service, teaching-material (books, testing papers, and electronic products) editing, publishing and selling, and so on. All these aim at making money by offering people extra training on English, which may enable people to pass certain English tests or examinations they are facing. Most of the training services are offered in the evenings, at weekends, or during holidays or vacations when students and working people do not have to go to school or work, resulting in such social phenomenon that people (students or working people) spend much time, money, and energy rushing here and there attending to different training programs at the time when they should be staying at home relaxing themselves and enjoying life. It seems that the whole society is involved in the training and learning of English, so that some foreign observers exclaim that the Chinese society is crazy about learning English! But on the other hand, except in the English classes in or out of schools and in various tests and examinations, people can hardly find any place or occasion to use English for real communication in the society. What a sharp contrast and conflict English brings to people’s life! No wonder so many people so strongly oppose to putting English in the compulsory position in school education, and regarding it as a rigid criterion of job-offering or rank-promotion in the society by means of offering tests and examinations of different types and levels.

\section{Conclusions: English Can Stand Somewhere}

Like many other people, as a learner and a teacher of English in China, the author is against the compulsory status of English in school education of all levels and in different kinds of tests, because such a status of English in China's schools (from primary schools to universities) and society has caused, and is still causing, a lot of negative effects upon school education, and upon people's social life, as the author has discussed above. The author would propose that English be put in a right place in people's education and life.

The author thinks the root of the phenomena she discussed above concerning English lies in the educational system of the country, which stipulates that a foreign language, mostly English, should be learned as a compulsory course by students in schools of different levels, from primary school pupils to university students (including undergraduates and postgraduates working at their master's or doctor's degrees). 
Accordingly, joy-offerers in the society produce their criteria of choosing employees, requiring them to have certificates proving their foreign language levels to be considered qualified for the positions to be filled. Consequently, nearly all people, children or adults, are forced to struggle with English almost throughout their learning and working years for utilitarian purposes instead of for real needs in life. How wrong it is to force a foreign language, here English, on people!

To put English in a suitable place in China, the first and foremost thing, the author believes, is for the government to revise the stipulations in its educational system concerning foreign language education, in accordance with the actual role of foreign languages in the development of the country and in people's real life. The author would say, based on the present educational condition in China, it is more reasonable to make English an optional course for primary school pupils, considering the availability of enough qualified English teachers; make it a compulsory course for middle school students, considering the fact that English has become a global language, and it is necessary to help the young lay a basic foundation of English for them to decide whether to learn it further in the future; and make it optional for some college students (mostly those whose majors have little to do with English) while compulsory for others (mostly English majors or those whose majors are closely related to English).

Relevantly, it is also necessary to change the aims and means of judging and evaluating the performances of students' learning and teachers' teaching, for the means of evaluation and assessment directly determine the approaches to teaching and learning in schools. If the process of learning and teaching, instead of the exam results, is focused in the evaluation and assessment of education, teachers and students will pay more attention to what may happen and what is happening to them in class, and may find more new possibilities and novel ideas, share more common experiences and adventures together, and enjoy more pleasure of discovering, winning, and even risk-taking. If what is happening in the process of learning and teaching is emphasized in the evaluation and assessment of education, teachers at work may care more about students' individual ideas, needs, feelings, likes and dislikes, and difficulties, and thus know better of their students, convey more respect and appreciation for them, share more with them, and offer more relevant help to students in need; in response to the teachers' care, respect and appreciation, students may take more initiative in learning, work harder at their studies, become more willing and able to overcome difficulties, obtain more achievements from their hard work, and thus feel themselves more able, more important, more confident, and happier in learning, and want to learn even more.

The author also hopes that, on the basis of such a more sensible educational system on foreign language education of the government, job-offerers in the society change their criteria of hiring employees as far as English is concerned. For jobs closely related to English or strongly dependent on English abilities, they can ask applicants to prove their English competence, better by means of language practice (spoken or written) on the spot than in terms of handing in certificates of certain English tests. For jobs having nothing or little to do with English, they had better not require English background on applicants at all.

If these two ideals can come true, the position of English in China and in Chinese people's heart can be quite different. It can orient English to a healthier and more ecological way in the education and life of the Chinese people. If so, in most of the time in their personal development in learning or working, people can enjoy the freedom of deciding whether or not to learn English or pursue a career related to English. If they choose to be with English of their own will, they will be responsible for their own learning, managing to meet challenges, 
tackle hardships, handle problems, enjoy achievements, etc., in the process of learning it. If they choose not to be with English, with which the author thinks there is nothing wrong, they will also be responsible for their own decisions. And, they can start at any time when they want to learn it.

After all, the learning of English depends on the context in which it is learned: the aims and reasons for learning it, the classroom environment, the expectations of the teachers and the students, the teaching methods and approaches, the learning attitudes, strategies, and effects, and so on. At present, many people in China are still learning English mainly for utilitarian reasons. Let us expect that English can be placed in a right position in China, helping people to lead a more sustainable, healthier, richer, and happier life through a different perspective.

\section{References}

CAI, J. G. (2006). College English teaching: Review, reflection and research. Shanghai: Shanghai Foreign Language Education Press. Higher Education Research Institute of Sichuan Foreign Language College. (1993). Records of the important events of China's foreign language education (1949-1989). Beijing: Foreign Language Teaching and Research Press.

HU, C. D. (2000). English teaching method. Beijing: Higher Education Press.

LI, Y. L. (1988). History of the instruction of English in China. Shanghai: Shanghai Foreign Language Education Press.

XIE, B. X. (2011-2012). My story: Teaching English in China (Part i-v). Retrieved from http://www.jesusjazzbuddhism.org/my-story-teaching-english-in-china-part-i.html

XIE, B. X. (2011a). English in China today. Retrieved from http://www.jesusjazzbuddhism.org/english-in-china-today.html

XIE, B. X. (2011b). Learning English, a part of my life (Part i-x). Retrieved from http://www.jesusjazzbuddhism.org/learning-english-i.html

XIE, B. X. (2011c). Reflection on English in China today-From the perspective of Whitehead's organic philosophy. Culture Communication. Claremont, USA: Center for Process Studies (USA), No. 46.

ZHANG, Z. D. (2007). Zhang Zhengdong's anthology on English language education. Beijing: Foreign Language Teaching and Research Press. 